\title{
KAP Study towards Organ and Whole Body Donation in Medical, Dental \& Nursing Students: A Randomised Institutional Based Survey
}

\author{
Simmi Mehra', Munish Kumar Kakkar², Aparna Garg ${ }^{3}$ \\ ${ }^{1}$ Professor \& Head, Department of Anatomy, Mahatma Gandhi Medical College \& Hospital, Jaipur, Rajasthan, India, ${ }^{2}$ Professor \& Head, Department of Pediatrics, \\ Mahatma Gandhi Medical College \& Hospital, Jaipur, Rajasthan, India, ${ }^{3}$ Associate Professor, Department of Physiology, Mahatma Gandhi Medical College \& \\ Hospital, Jaipur, Rajasthan, India.
}

\section{Abstract}

Background: In our country more than 500,000 people suffer from non-availability of organ and waiting for a transplant. About 150,000 patients wait for kidneys, 50,000 for hearts and 50,000 for liver transplants approximately. Nearly 10, 00,000 people suffering from blindness need donors. In a country such as ours with a population of 1.3 billion, the donor rate is comparatively low i.e. just 0.4 per million population when compared to the USA where it accounts to around 25 per million. This data shows a huge variation between demand and availability. Subjects and Methods: A total of 175 students were involved in our study analysis. A total of 109 MBBS, 52 BDS and 14 nursing students were involved in the study analysis. The study was conducted using an objective type questionnaire. Results: Awareness regarding organ donation during life was analysed and students of MBBS were able to give most correct answers. Awareness regarding organ donation after life was also analysed and students of MBBS yet again had the most correct answers. Conclusion: It can be understood that an aware population of the medical personnel will help to promote the concept of organ/ whole body donation in the public and motivate them.

Keywords: Donation, Demand, Organ, Medical.

Corresponding Author: Dr. Simmi Mehra, Professor \& Head, Department of Anatomy, Mahatma Gandhi Medical College \& Hospital, Jaipur, Rajasthan, India.

Received: May 2019

Accepted: June 2019

\section{Introduction}

In our country more than 500,000 people suffer from nonavailability of organ and waiting for a transplant. About 150,000 patients wait for kidneys, 50,000 for hearts and 50,000 for liver transplants approximately. Nearly 10, 00,000 people suffering from blindness are in need of donors. In a country such as ours with a population of 1.3 billion, the donor rate is comparatively low i.e. just 0.4 per million population when compared to the USA where it accounts to around 25 per million. This data shows a huge variation between demand and availability. This deficit in requirement availability clearly shows the excessive delay in transplant surgeries, resulting in increased morbidity rate due to lack of organ donors. This leads to a situation serving as a potential for illicit organ traders. So, without any doubts it can be stated that strengthening the donor pool is the only viable solution for these problems. Apt knowledge of anatomy is totally imperative for medical practitioners. Dissection and organ analysis of cadavers remains the most powerful means of teaching and learning anatomy for a doctor. The sudden increase of medical colleges has led to lack of viable cadavers for study analysis. This cadaver scarcity can only be overcome by motivating and educating the public on the importance of whole-body donation. This current research focuses to explore the levels of knowledge and attitudes of upcoming health professionals towards organ and whole-body donation. The medical intellect of a medical student is influenced by their exposure to dissection by a great extent, but sadly they are reluctant to become involved in body donation process. ${ }^{[1]}$ The present study was conducted with the aim to determine the knowledge and attitude of Medical, Dental \& Nursing students towards organ and whole body donation.

\section{Subjects and Methods}

A prior ethical approval was obtained from the Institutional Ethics Committee. A total of 175 students were involved in our study analysis conducted at Department of Anatomy, Mahatma Gandhi Medical College \& Hospital, Jaipur, Rajasthan, India. A total of 109 first year MBBS, 52 first year BDS and 14 first year M.Sc Nursing students were involved in the study analysis. The study was conducted for a period of one year. An objective type questionnaire was designed to analyse the knowledge, mind-set, apprehension and fears with respect to organ and whole body donation. The pilot questionnaire was designed to analyse the appropriate qualitative and quantitative extent of organ and whole body donation know-how among the medical students. All the participants were briefly explained the 
objective of the analysis and were assured anonymity and only those who willingly gave consent were included in the study. All the 21 questions were answered and were later on interpreted electronically for analysis. All the data was arranged in tabulated form and analysed using SPSS software. Percentage of all the data was obtained.

\section{Results}

The results so obtained were interpreted electronically. All the students had a general idea for the organ donation and were able to answer all the questions confidently. Awareness regarding organ donation/ whole body donation during life was analysed and students of MBBS were able to give most correct answers. [Figure 1] Awareness regarding organ donation after life was also analysed and students of MBBS yet again had the most correct answers. [Figure 2] Considering the attitude towards the organ donation, most students of BDS were willing to organ donation and/or whole body donation. [Figure 3] All the reasons of non-willingness and apprehension regarding organ donation were shown in [Table 1]. Religious reasons and fear were the most dominating.

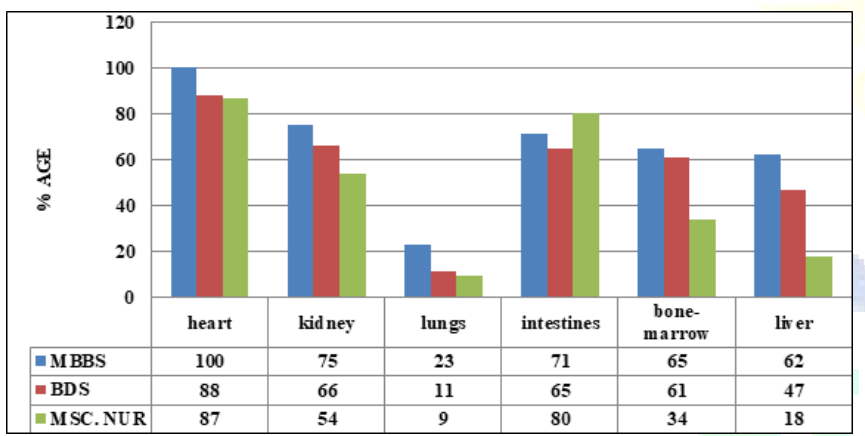

Figure 1: Awareness regarding organ donation during life.

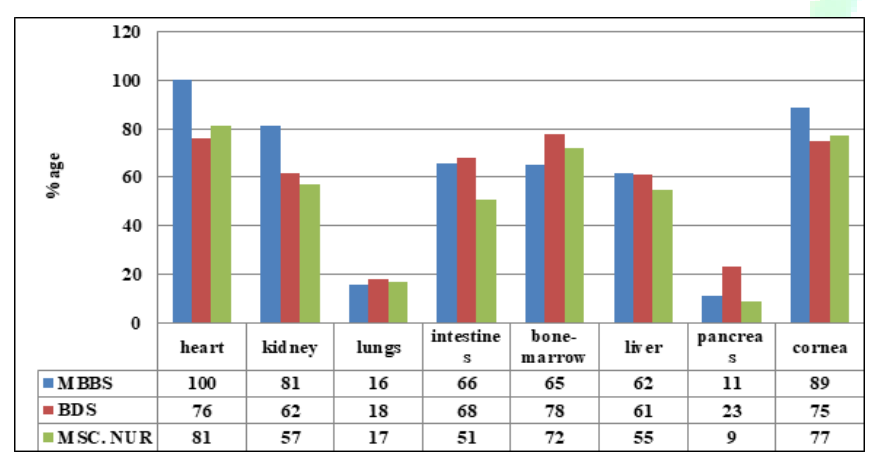

Figure 2: Awareness regarding organ donation after life.

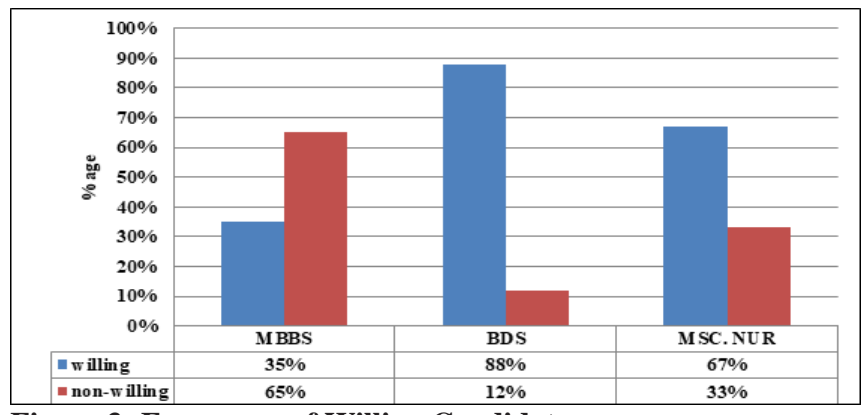

Table 1: Frequency of medical students (reasons of nonwillingness and apprehension)

\begin{tabular}{|l|l|l|l|l|l|}
\hline $\begin{array}{l}\text { COURS } \\
\text { E }\end{array}$ & $\begin{array}{l}\text { Fami } \\
\text { ly }\end{array}$ & $\begin{array}{l}\text { Religio } \\
\text { us }\end{array}$ & $\begin{array}{l}\text { Fea } \\
\text { r }\end{array}$ & $\begin{array}{l}\text { Disrespect to } \\
\text { body }\end{array}$ & $\begin{array}{l}\text { No } \\
\text { Reason }\end{array}$ \\
\hline MBBS & $32 \%$ & $11 \%$ & $9 \%$ & $10 \%$ & $3 \%$ \\
\hline BDS & $8 \%$ & $1 \%$ & $1 \%$ & $1 \%$ & $1 \%$ \\
\hline $\begin{array}{l}\text { MSC. } \\
\text { NUR }\end{array}$ & $12 \%$ & $8 \%$ & $2 \%$ & $7 \%$ & $4 \%$ \\
\hline
\end{tabular}

\section{Discussion}

The participants in the study had a fair knowledge of brain death, organ donation and whole-body donation. Compared to the BDS and MSc nursing students, the MBBS were well informed of the various aspects of organ donation as is also observed in results of another cross sectional study conducted by Majeed (2016). ${ }^{[2]}$ Higher the score obtained in present study might be a result to the incorporation of such topics in their first year curriculum as well as a relatively early clinical exposure of this group of students. Among all the categories, majority students were willing to donate organs, when compared with whole body donation. Considering whole body donation, majority of the students were against the idea. The reasons of non- willingness for organ and body donation were vast. Most of the students were not able to give any specific reasons for their stand. Some of the students showed apprehension due to the objection from their families ${ }^{[3,4]}$ A few students even cited fear and disinterest as explanation for the apathetic attitude. On deeper analysis it became evident that the disrespect shown to the cadaver by fellow students that changed their outlook towards whole body donation. ${ }^{[5]}$ Thus, promoting negative attitude towards organ and corpse donation. The main reason for unwillingness to self-donate emerged as religious beliefs. ${ }^{[6]}$ Appropriate remedial measures should be incorporated to promote organ and whole body donation. By simply accessing to the relevant information will promote the unresolved attitude to mould in favour of donation. ${ }^{[7]}$ Our medical curriculum should highlight and promote the importance of organ donation, therefore improving the attitudes of health care professionals could help to promote organ donation. ${ }^{[8,9]}$ An earlier unwilling mind might change his or her opinion when the concept is instilled into them as part of their studies, over the years. ${ }^{[10]}$ As a solution discussions with religious scholars may help in complying fears and anxiety in devout potential donors. As a potential donor population, medical students show apprehension towards any emotional involvement in the donation process and are absolutely not willing to become donors themselves, nothing much can be expected from the general population. ${ }^{[11]}$ Students learning anatomy must develop the habit of handling the body with respect and dignity. They must learn to honour the dead who had aid in teach the living. Even the teachers must ensure that students follow proper ethics and good practices in human cadaveric dissection. ${ }^{[12]}$

\section{Conclusion}


It can be understood that a well aware population of the medical personnel will help to promote the concept of organ/ whole body donation in the public and motivate them. Negative attitudes expressed during the analysis should be examined by the authorities with seriousness and appropriate remedial measures be made after enough discussion with the people concerned.

\section{References}

1. Aneja PS, Bansal S, Sood KS, et al. Body donation - a dilemma among doctors. JEMDS 2013;2(16):2585-93.

2. Majeed F. Saudi nursing and medical student's knowledge and attitude towards organ donation - a comparative cross sectional study. Int Journal Health Sci (Qassim) 2016;10(2):209-17.

3. Anyanwu EG, Obikili EN, Agu AN. The dissection room experience: A factor in the choice of organ and whole body donation - a Nigerian survey. Anatomical Sciences Education 2014;7(1):56-63.

4. De Gama BZ, Bhengu TT, Satyapal KS. Attitudes of undergraduate South African students towards body donation. Int $\mathrm{J}$ Morphol 2018;36(1):130-4.

5. Abimbola OE, Chukwuedu O, Alabi A. Perception of organ \& corpse donation among students of basic medical sciences. Int $\mathrm{J}$ of Forensic Med Invest 2016;2(1):9-12.

6. Mwachaka PM, Mandela P, Saidi H. Repeated exposure to dissection does not influence students' attitudes towards human body donation for anatomy teaching. Article ID 9251049, Anatomy Research International 2016;2016: p. 5.

7. Terbonssen T, Settmacher U, Wurst C, et al. Attitude towards organ donation in German medical students. Langenbecks Arch Surg 2016;401(8):1231-9.

8. Mekahli D, Liutkus A, Fargue S, et al. Survey of first year medical students to assess their knowledge and attitude towards organ transplantation and donation. Transplant Proc 2009;41(2):634-8.

9. Hamed H, Awad ME, Youssef KN, et al. Knowledge and attitudes about organ donation among medical students in Egypt: a questionnaire. Journal of Transplantation Technologies \& Research 2016;6(1):155.

10. Figueroa CA, Mesfum ET, Acton NT, et al. Medical students' knowledge and attitude towards organ donation: results of a Dutch survey. Transplant Proc 2013;45(6):2093-7.

11. Rokade SA, Gaikawad AP. Body donation in India: social awareness willingness \& associated factors. Anat Sci Educ 2012;5(2):83-9.

12. Ghosh SK. Paying respect to human cadavers: we owe this to the first teacher of anatomy. Ann Anat 2017;211:129-34.

Copyright: (C) the author(s), 2019. It is an open-access article distributed under the terms of the Creative Commons Attribution License (CC BY 4.0), which permits authors to retain ownership of the copyright for their content, and allow anyone to download, reuse, reprint, modify, distribute and/or copy the content as long as the original authors and source are cited.

How to cite this article: Mehra S, Kakkar MK, Garg A. KAP Study towards Organ and Whole Body Donation in Medical, Dental \& Nursing Students: A Randomised Institutional Based Survey. Asian J. Med. Res. 2019;8(3):AT01-AT03.

DOI: dx.doi.org/10.21276/ajmr.2019.8.3.AT1

Source of Support: Nil, Conflict of Interest: None declared.

Questionnaire
\begin{tabular}{|l|l|}
\hline 1. & Have you heard of organ/whole body donation. \\
\hline 2. & Are you aware of ACTS regarding Transplantation of human organs / Body donation \\
\hline 3. & What do you understand by brain death. \\
\hline 4. & Do you know where to obtain organ donation cards. \\
\hline 5. & Who can donate body. \\
\hline 6. & Uses of donated body. \\
\hline 7. & Can a brain dead patient's organs be donated. \\
\hline 8. & Do you support donation of organs/ whole body donation. \\
\hline 9. & Do you feel comfortable to think or talk about organ/body donation. \\
\hline 10. & Do you agree to donate your organs/ body when you die. \\
\hline 11. & Do you agree to donate your family member's body/ organs. \\
\hline 12. & Do you know the reasons for rejecting body donation. \\
\hline 13. & Do you have fear that your body will be disfigured if you donate your organs. \\
\hline 14. & Does your family agree with body/organ donation. \\
\hline 15. & Does your religion agree with body/ organ donation. \\
\hline 16. & Do you fear that your body will be disrespected if you donate your body. \\
\hline 17. & Do you think live organ donation is better than cadaveric organ donation in solving the shortage. \\
\hline 18. & Has anybody in your family donated body/organs. \\
\hline 19. & Which organs will you prefer to donate. \\
\hline 20. & Emotions of your family members while organ/body donation \\
\hline 21. & Have you pledged/ signed to donate your organs for transplantation. \\
\hline
\end{tabular}

